УДК 159.9:053.66:376.37

https://doi.org/10.52058/2708-7530-2021-11(17)-401-411

Щербакова Ірина Миколаївна доцент, кандидат філософських наук, доцент кафедри психології, Сумський державний педагогічний університет імені А.С. Макаренка, вул. Роменська, 87, м. Суми, 40002, тел.: (0542) 68-59-02, e-mail: ishcherbakova@ukr.net, https://orcid.org/0000-0001-5900-5189

Харченко Тамара Григорова кандидат психологічних наук, викладач кафедри логопедії, Сумський державний педагогічний університет імені А.С.Макаренка, вул. Роменська, 87, м. Суми, 40002, тел.: (0542) 68-59-02, e-mail: kharchenko88@gmail.com https://orcid.org/0000-0002-4239-3434

\title{
ПОВЕДІНКА ДІТЕЙ МОЛОДШОГО ШКІЛЬНОГО ВІКУ ІЗ МОВЛЕННСВИМИ ПОРУШЕННЯМИ
}

Анотація. У статті представлено результати теоретичного аналізу досліджень вітчизняних та зарубіжних вчених щодо порушень поведінки у дітей молодшого шкільного віку із порушеннями мовлення. Визначено що такі діти на фоні мовленнєвих $\mathrm{i}$ немовленнєвих дефектів мають труднощі формування соціально-комунікативних навичок, мають різні поведінкові розлади. 3'ясовано, що негативними проявами поведінки у дітей молодшого шкільного із мовленнєвими порушеннями є поведінкові протести, різні форми агресивно-бунтівної поведінки. Обгрунтовано наявність у таких дітей специфічних типів конфліктної поведінки, а також пасивної поведінки, тим що поведінкові порушення пов'язані із мовленнсвими порушеннями, які обумовлюють різні поведінкові статуси дітей (від позитивного до негативного).

Визначено тенденцію схильності до негативних проявів поведінки дітей із мовленнєвими порушеннями, які сприймають або відверто ігнорують норми поведінки, внаслідок чого їх поведінка надуває соціально небажаного забарвлення. Основними видами поведінкових реакцій дітей із мовленнєвими порушеннями $\epsilon$ рухлива-розгальмованість, агресивна вразливість, надмірна боязкість, агресивна-байдужість, опозиційно-зухвала поведінка. Ступінь тяжкості мовленнєвого порушення обумовлює специфічний характер спілкування й посилює негативні форми поведінки дітей із мовленнєвими порушеннями, які незацікавлені у налагодженні мовленнєвих контактів. Залежно від рівня комунікативних порушень виділяють наступні типологічні групи: діти з нульовим ступенем фіксації на порушенні; діти із труднощами у процесі встановлення контакту з іншими людьми; діти із постійною фіксацією на своїх мовленнєвих невдачах. Такі діти дезорієнтується в нових ситуаціях

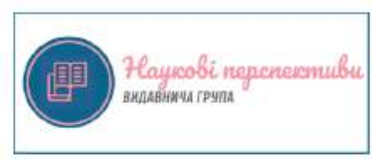


спілкування. Надмірна агресивність, упертість, емоційна неврівноваженість й конфліктність характеризують стійкі поведінкові реакції. У підсумку визначено, що дизонтогенез комунікативно-мовленнєвого розвитку дітей молодшого шкільного віку із мовленнєвими порушеннями провокує значні зміни на конативному рівні (поведінковому). Основними симптомами дезадаптивної поведінки дітей молодшого шкільного віку із мовленнєвими порушеннями є агресія, надмірна активність, упертість, емоційні розлади, почуття власної неповноцінності, неадекватні фобії, підвищена збудливість і конфліктність.

Ключові слова: порушення мовлення, поведінка, дитина молодшого шкільного віку, агресивність, упертість, емоційна неврівноваженість.

Shcherbakova Iryna Nikolaevna Candidate of philosophical sciences, associate professor at the department of psychology Sumy State A. S. Makarenko Pedagogical University, Romenska St., 87, Sumy, 40002, tel.: (0542) 68-59-02, e-mail: ishcherbakova@ukr.net, https://orcid.org/0000-0001-5900-5189

Kharchenko Tamara Grigorovna Candidate of psychological sciences, lecturer of the department of logopedy Sumy State A.S. Makarenko Pedagogical University, Romenska St., 87, Sumy, 40002, tel.: (0542) 68-59-02, e-mail: kharchenko88@gmail.com, https://orcid.org/0000-0002-4239-3434

\section{BEHAVIOUR OF CHILDREN OF PRIMARY SCHOOL AGE WITH SPEECH DISORDERS}

Abstract. The article presents the theoretical predictions of studies of domestic and foreign scientists on behavioural disorders in children of primary school age with speech disorders. It is determined that such children, against the background of speech and non-speech defects, experience difficulties in forming sociocommunicative skills, have various behavioural disorders. It has been found that negative manifestations of behaviour in primary school children with speech disorders are behavioural protests, different forms of aggressive-rebellious behaviour. It is justified that such children have specific types of conflict behaviour, as well as passive behaviour, in that behavioural disorders are associated with speech disorders that cause different behavioural statuses of children (from positive to negative).

The tendency to tend to negative manifestations of the behaviour of children with logopathy perceiving or frankly ignoring norms of behaviour is determined, as a result of which their behaviour acquires a socially undesirable colour. The main types of behavioural reactions of children with logopathy are mobile relaxation, aggressive vulnerability, excessive timidity, aggressive indifference, oppositiondaring behaviour. The severity of speech impairment determines the specific nature 
of communication and enhances the negative behaviours of children with logopathy who are not interested in establishing speech contacts. Depending on the level of communicative disorders, the following typological groups are distinguished: children with zero degrees of fixation for violation; Children with difficulties in contacting others; children with a permanent fixation on their speech failures. Such children become disoriented in new situations of communication. Excessive aggressiveness, stubbornness, emotional imbalance and conflict characterize persistent behavioural responses. As a result, it was determined that the dysontogenesis of communicative-speech development of children of primary school age with speech disorders provokes significant changes at the conative level (behavioural). The main symptoms of maladaptive behaviour of primary school children with speech disorders are aggression, excessive activity, stubbornness, emotional disorders, inadequacy, inadequate phobias, hypermotivity and proneness to conflict.

Keywords: articulation disorders, behaviour, primary school-age child, aggressiveness, stubbornness, emotional imbalance.

Постановка проблеми. Розпорядженням Кабінету Міністрів України від 9 серпня 2017 р. №526-р «Про Національну стратегію реформування системи інституційного догляду та виховання дітей на 2017-2026 роки та план заходів 3 реалізації іiі I етапу» передбачено зменшити до 2026 року кількість дітей, що проживають не в родинах, та створити сприятливі умови для отримання дітьми iз особливими освітніми потребами (далі - ДООП) можливості здобувати освіту за місцем проживання. У пояснювальній записці йдеться про припинення набору учнів із ЗПР до спеціальних шкіл (станом на 2018-2019 н.р), але наголошується що значний відсоток дітей із ТПМ продовжують отримувати освіту у спеціалізованих закладах освіти [11].

В умовах кризового сьогодення, а саме невизначеності, ізоляції, дистанціювання та карантинних обмежень, прийшло нове розуміння того, яким важливим $\epsilon$ своєчасне створення сприятливих умов розвитку й життєдіяльності, особливо для соціально незахищених категорій населення, зокрема дітей з особливими освітніми потребами [15]. Станом на 30 серпня 2021 року, методичними рекомендаціями організації навчання ДООП, опублікованими на сайті МОН України визначено пріоритетні завданнями реалізації Національної стратегії зі створення безбар'єрного простору в Україні на період до 2030 року. Методичні рекомендації укладено 3 урахуванням специфіки дистанційного навчання та схвалено розпорядженням Кабінету Міністрів України від 14 квітня 2021 р. № 366-року. В рекомендаціях визначено пріоритети, зокрема «створення рівних можливостей та вільного доступу до освіти, задоволення особливих освітніх потреб усіх учасників освітнього процесу, створення інклюзивного освітнього середовища» [6] (Лист МOH 30.08.2021.). Отже, ми $є$ свідками кардинальних трансформацій 
інклюзивного освітнього середовища, яке швидко змінюється впливаючи на поведінку суб'єктів освіти.

Аналіз останніх досліджень і публікацій. Теоретичний аналіз досліджень поведінки у вітчизняній й закордонній психології дозволив нам 3'ясувати відсутність грунтовних досліджень наукової дефініції «поведінка». Свого часу, на цей факт звернув увагу професор Т. Герасимів, вказавши що «вичерпного спеціального соціально-філософського осмислення та наукового аналізу проблеми «поведінки» особистості не було взагалі. Це - наслідок недостатнього розроблення проблематики поведінки особистості й у теоретичному, і в практичному аспектах» [3]. Маємо визнати наявність поодиноких досліджень поведінки дітей із мовленнєвими порушеннями, де предметом дослідження є категорія «поведінка», а не вплив мовленнєвих порушень на поведінку дітей молодшого шкільного віку.

Представники логопсихології звертають увагу на той факт, що серед дітей молодшого шкільного віку з мовленнєвими порушеннями прослідковується стійка схильність до систематичних порушень комунікативного акту. Дослідженням спілкування і актів поведінки дітей молодшого шкільного віку iз мовленнєвих порушеннями займались вітчизняні (Бойко Ю., Бондар М., Бугера Ю., Грибова О., Кардаш Н., Косарєва О., Мартиненко І., Рібцун Ю., Сєромаха Н., Сидорко Т.В., Токарева Н.М., Тищенко І.Д., Царева Ю. В., Цибуля Н.В., Шамне А., Шипіцина Л., Якимчук Г.) та закордонні (Waller Marcie, Sollod Robert, Sander Eric, and Kunicki Elizabeth, Dixie Jordan, Meme Hieneman, Mike Nolan, Judy Presley, Lynn De Turo, Winnie Gayler, Glen Dunlap) науковці.

Мета статті - визначити психологічні особливості поведінки дітей молодшого віку із мовленнєвими порушеннями.

Виклад основного матеріалу. Дослідження поведінки завжди характеризувались дискусійним характером, адже за слушним зауваженням Панчишин P.I., поведінку «...не можна розглядати одновимірно і прямолінійно, iï необхідно вивчати i актуалізувати в контексті еволюції, проводити диференціацію за змістовною сутністю і цілеспрямованістю іï дій» [8]. Поведінка зазвичай аналізується через зміст понять: «дія», «вчинок», «активність», «потреба», «інтерес», «мотивація», «мета», «спілкування», «діяльність». У словнику української мови слово «поведінка» визначено у чотирьох значеннях: як сукупність дій і вчинків; спосіб життя; як конкретні дії, або сукупність дій, тобто вчинки; як уміння поводитися відповідно до правил; як реакція живого організму на подразник (Словник української мови, 1975).

Філософський енциклопедичний словник подає визначення поведінки як «процес зміни станів певної речі або істоти, що відповідає їхній внутрішній природі як цілому. Важливою для загального осмислення поняття поведінки є його етимологічна основа, що вказує на «поведення», «ведення» себе, «володіння» собою (behaviour)» [12]. У психологічному словнику поведінка 
витлумачується як «зовнішній прояв діяльності, система дій індивіда, спрямовану на підтримку свого існування. Це особливим чином організована психічна діяльність, що проявляється в певній послідовності вчинків, цілеспрямованих дій. Необхідними детермінантами поведінки людини $є$ мотиви і цілі, що зумовлюються соціально-історичною практикою» [9].

Панчишин P.І. висловлюючи думку, що у науковій літературі поведінка зазвичай характеризується як система дій людини або тварин, визначає зміст поведінки як систему внутрішньо взаємозалежних дій, які здійснює якийнебудь складний об’єкт, дій спрямованих на реалізацію того, що потребує об’єкт [8]. Максименко С.Д. визначає поведінку як систему одиничних або комплексних рухів, де елементами зовнішньої поведінки (руху) є дії, які обумовлюються внутрішніми процесами (внутрішніми рухами) [4]. За Т. Герасимів поведінка є комплексом дій і вчинків, вияву та форми діяльності. Визначаючи поведінку, як систему дій, Герасимів Т. подає визначення поведінки за Щепанським Я., визначаючи поведінку як сукупність послідовних учинків або систему дій людини [3]. Натомість аналізуючи підходи науковців до розуміння поведінки людини, Барабаш О.О вказує на залежність видів поведінки від форм іiі вираження (характеризує види поведінки за Оксамитним В.В.: вербальна, реальна поведінка), а також виділяє чотири підходи до розуміння поведінки: біологічний, психологічним, соціологічний, персоналістський (за Козенко Ю.О.) [1]. Бочелюк В.Й. досліджуючи соціально-психологічні мотиви і механізми поведінки людини зауважує, що людська поведінка «це не поведінка, «спрямована до мети», а поведінка, яка «спрямовується метою». Мета дає людині уявлення про бажані для неї результати дії, виражає певний рівень домагань» [2].

Вище наведене дозволяє стверджувати, що розуміння поведінки як власне людської характеристики, передбачає здатність людини до самоорганізації та позначає спосіб існування людини. У філософському словнику наголошено, що «людська поведінка корелює зі складною системою цілей, мотивів, настанов, внутрішніх смислів, свідомих та неусвідомлених прагнень і потягів, завжди так чи інакше поєднаних і актуалізованих певним рішенням суб'єкта стосовно способу своєї присутності у світі» [12]. На нашу думку, поведінка $є$ дієвою, вчинковою активністю людини, характер якої визначається наявністю або відсутність наміру діяти певним чином та актуальним потребовомотиваційним станом особистості. Таке авторське витлумачування змісту поняття «поведінка», на нашу думку, не суперечить науковій практиці. Визначаючи специфіку поведінки дітей молодшого шкільного віку із мовленнєвими порушеннями, вважаємо що критерієм аналізу має бути наявність або відсутність у дитини наміру робити ту чи іншу дію, або не робити будь що взагалі. Складність аналізу поведінки дітей молодшого шкільного віку із мовленнєвими порушеннями полягає не стільки у визначенні ii відповідності нормативним критеріям (віковим поведінковим нормам)

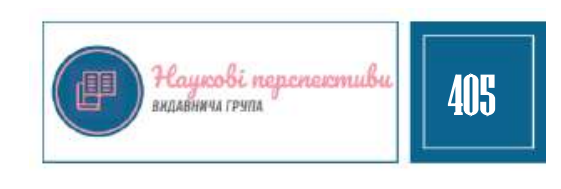


виконуваних дій, скільки в тому, наскільки дії дитини відповідають суспільним очікуванням, тобто «нормі» у розумінні самої дитини. Зрозуміло, що по відношенню до ДООП поняття «норма» як і поняття «відхилення від норми» набувають специфічного значення.

Відхиленнями у поведінці людини в широкому сенсі слід розуміти будь які дії, які «не відповідають писаним i неписаним, формальним i неформальним нормам. У вузькому розумінні вони відносяться тільки до неписаних норм. Характерна риса такої поведінки - релятивність норми: 3 однієї точки зору така поведінка може вважатися нормальною, 3 іншої ця ж поведінка є відхиленням від норми. Цим пояснюється, що кордони терпимості суспільства до таких проявів поведінки можуть бути різні...» [8]. Симптомами дезадаптивної поведінки, на думку Матющенко I.M. є: агресія по відношенню до людей і речей, надмірна активність, постійне фантазування, упертість, систематичні емоційні розлади, почуття власної неповноцінності, неадекватні фобії, підвищена збудливість і конфліктність, нездатність зосереджуватись на роботі, невпевненість у прийнятті рішень, неправдивість, надмірна похмурість i незадоволеність, завищена самооцінка, постійні втечі зі школи та дому, смоктання пальців, гризіння нігтів, енурез, тремор рук і ніг [5].

Діти 3 негативними поведінковими проявами, за визначенням Осауленко Л.А., це діти із порушеним ставленням до норм поведінки. Під впливом несприятливих умов життя, неправильного виховання у поведінці таких дітей 3'являються агресивність, жорстокість, байдужість, жадібність, брехливість [7]. Впевнені, що такі узагальнення мають бути обгрунтованими, для цього аналіз конкретних проявів поведінки молодших школярів із мовленнєвими порушеннями має починатись із визначення того, як негативні прояви поведінки дитини пов'язані iз іï мовленнєвим порушенням, специфікою індивідуально-типологічних особливостей особистості. Дослідивши існуючі класифікації порушень мовлення, ми зосередили увагу на характеристиці видів мовленнєвих порушень за Рибцун Юлією, та проаналізували критерії комплексної діагностики мовленнєвого розвитку молодших школярів [10].

Узагальнюючи інформацію про види порушень мовленнєвого розвитку у дітей молодшого шкільного віку, для зручності ми ввели абревіатури «ПУМ» (порушення усного мовлення), «ППМ» (порушення писемного мовлення) та визначили види ПУМ / ППМ молодших школярів й критерії характеристики поведінки ДООП як предмету логопедичного обстеження або комплексної психологічної діагностики Рис.1. 


\begin{tabular}{|c|c|c|c|}
\hline \multicolumn{4}{|c|}{ Види порушень мовленнєвого розвитку: ПУМ/ПІІМ } \\
\hline \multicolumn{4}{|c|}{ ПуМ (поруиення усного мовлення): фонетико-фонематичні } \\
\hline дислалі & & pтрія & рннолалія \\
\hline \multicolumn{4}{|c|}{$\begin{array}{c}\text { ПУМ (поруиення усного мовлення): лексико-граматичні } \\
\text { (загальний недорозвнток мовлення) }\end{array}$} \\
\hline алалія & афазія & днзартрія & рннолалія \\
\hline \multicolumn{4}{|c|}{ ПУМ (поруиення усного мовлення): мелодико-інтонаційні } \\
\hline & дисфонія, & & афонія \\
\hline \multicolumn{4}{|c|}{ ПуМ (поруиення усного мовлення): темпо-ритмічні } \\
\hline браднлалія & тахілалія & заїкання & полтерн \\
\hline \multicolumn{4}{|c|}{ IIIM (поруиення писемного мовлення): при писанні } \\
\hline & дисграфія & дизор & афія \\
\hline \multicolumn{4}{|c|}{ IIIM (поруиення писеиного мовлення): при читанні } \\
\hline \multicolumn{4}{|c|}{ дислексія } \\
\hline \multicolumn{4}{|c|}{\begin{tabular}{r}
\multicolumn{2}{|c}{ Предмет обстеження поведінки як складової } \\
мовленнєвого розвитку
\end{tabular}} \\
\hline Поведінка & $\begin{array}{r}\text { активність, } \\
\text { соціальних } \\
\text { нерівномірніст } \\
\end{array}$ & $\begin{array}{l}\text { нчність, самс } \\
\text { м; характер в } \\
\text { еадекватність }\end{array}$ & $\begin{array}{l}\text { гляція, дотримання } \\
\text { годії } 3 \text { дорослими; } \\
\text { ативізм, агресивність }\end{array}$ \\
\hline Опори & $\begin{array}{l}\text { (B) - інструкцій, } \\
\text { (Е) - усмішка, пр }\end{array}$ & $\begin{array}{l}\text { алізація, поя } \\
\text { жування по }\end{array}$ & $\begin{array}{l}\text { ня, навідні запитання. } \\
\text { голові. }\end{array}$ \\
\hline
\end{tabular}

Рис. 1. Класифікатор видів порушень мовленнєвого розвитку, критеріїв та опор дослідження поведінки дітей молодшого шкільного віку із мовленнєвими порушеннями (за Щербаковою І.М., Харченко Т.Г).

Аналізуючи поведінку дітей молодшого шкільного віку, окрему увагу необхідно приділяти самооцінці та рівню саморегуляції поведінки. Про залежність поведінки дітей молодшого шкільного віку від характеру самооцінки та впливу оцінювання дитини зовні ми зазначали у попередніх дослідженнях, де зокрема визначили чинники психологічного аналізу взаємозв'язку самооцінки, тривожності, саморегуляції поведінки, стилю поведінки [13]. Характеризуючи стиль та саморегуляцію поведінки доречно звертати увагу на такі полярні критерії, як: здатність/нездатність дитини брати відповідальність за акти поведінки; бажання/небажання бути відповідальною за власні дії, вчинки.

Вважаємо за необхідне наголосити на доцільності аналізу форм прояву поведінки дітей молодшого шкільного віку, а саме визначенні стилю поведінки, який у свою чергу визначається неусвідомлюваними мотивами, зовнішнім підкріпленням, фізіологічними процесами, генетичними особливостями, культурою, а також досвідом дитинства (далі - ДД). На нашу думку, ДД дорівнює сумі ЕДС та ЕДВД, де ЕДС - емоційний досвід спілкування, ЕДВД - емоційний досвід виконання діяльності. Критеріями факторного аналізу поведінки ми визначили: 1) проактивність / реактивність поведінки; 2) орієнтацією «на інших / від інших / проти інших (дозволить 3'ясувати поступливою, відокремленою або ворожою є поведінка дитини із мовленнєвими порушеннями); 3) рівень самооцінювання (самооцінка залежна, 
агресивна, упевнена). Аналізуючи поведінку дитини молодшого шкільного віку із мовленнєвими порушеннями необхідно з'ясувати: 1) схильність дитини до конфліктної поведінки; 2) тип конфліктної поведінки: агресивний (ініціація конфліктів) або демонстративний (привернення уваги); характер конфліктної поведінки: пасивний (як зовнішньо-внутрішнє підпорядкування на фоні заниженої самооцінки); активний (як зовнішнє підпорядкування на фоні афективних спалахів).

Dixie Jordan звертає увагу, що дуже багато дітей мають неадекватну поведінку не тільки через порушення які вони мають, а насамперед через специфіку середовища в якому перебуває дитина. Слід враховувати, що більшість видів поведінки пов'язані 3 їхнім контекстом [14]. Причини агресивної поведінки обумовлюються як зовнішніми, так i внутрішніми факторами. Так, Dixie Jordan визначив п’ятірку факторів, які обумовлюють проблеми у поведінці: непорозуміння між дітьми; кількість дітей у класі; динаміка взаємодії з однолітками; розмір класної кімнати; складні види навчальної діяльності [14]. Waller Marcie, Sollod Robert, Sander Eric, and Kunicki Elizabeth зауважують, що негативізм, провокаційна поведінка можуть бути проявом неслухняності дитини, або так званою провокаційноопозиційною позицією по відношенню до дорослих, авторитетних осіб [16].

На думку Осауленко Л.А. при переході дитини від дошкільного до молодшого шкільного віку можуть спостерігатись такі прояви негативної поведінки: схильність робити все навпаки; навмисне ігнорування або свідомі дії наперекір дорослим; упертість; непокірності (поведінковий протест як прояв неслухняності); самовілля (свавілля, як домагання самостійності), агресивно-бунтівна поведінка або навіть деспотизм (крайня форма свавільності). На основі домінуючого типу агресії, який прослідковується у поведінці дитини, Осауленко Л.А. запропонувала наступну типологію дітей із мовленнєвими порушеннями: 1) гіперактивно-агресивна дитина (рухливорозгальмована дитина); 2) агресивно-вразлива дитина (основна риса вразливість); 3) агресивно-боязка дитина (основна риса - надмірна боязкість); 4) агресивно-байдужа дитина (дитина грубіян); 5) агресивна дитина 3 опозиційно-зухвалою поведінкою (дитини, яка грубіянить дорослим) [7].

Враховуючи обумовленість характеру поведінкових реакцій значною кількістю контекстних факторів, зокрема зовнішніх впливів, на нашу думку, в умовах карантинних обмежень спричинених пандемією, поведінці дітей молодшого шкільного віку із мовленнєвим и порушеннями слід приділяти більш пильну увагу. Ми зазначали, що до пандемії (до дистанційного навчання) головна складність полягала у самій специфіці навчання дітей 3 особливими потребами. Такі діти фізично були не здатні постійно перебувати в класі, сидіти на всіх уроках, бути присутніми на всіх шкільних заходах. Процес навчання в інклюзивних класах проходив на двох рівнях. По-перше, пояснення для більшості класу, а по-друге паралельний уточнюючий супровід 
цього пояснення для особливих дітей. Під час дистанційного навчання ситуація змінилась [15]. В умовах дистанційного навчання посилилась тривожність дітей із мовленнєвими порушеннями. Ми також з'ясували що у молодших школярів тривожність $є$ результатом фрустрації потреби в захищеності 3 боку найближчого оточення. Діти із мовленнєвими порушеннями фрустровані значно більше. У таких дітей рівень фрустрації потреби в захищеності обумовлюється, як мовленнєвими порушеннями, так і особливостями міжособистісних зав'язків з іншими [13].

Висновки. Встановлено, що мовленнєві порушення обумовлюють специфічний характер спілкування й поведінки дітей із мовленнєвими порушеннями, що обмеженість вербальних засобів спілкування обумовлює появу стійких порушень комунікативного акту. Низький рівень мовленнєвої активності $є$ причиною незацікавленості дітей молодшого шкільного віку із мовленнєвими порушеннями у налагодженні мовленнєвих контактів. Такі діти дезорієнтується в нових ситуаціях спілкування. Залежно від рівня комунікативних порушень слід виділяти дітей: з нульовим ступенем фіксації на порушеннях, із труднощами у процесі встановлення контакту 3 іншими людьми, iз постійною фіксацією на своїх мовленнєвих невдачах. Специфічними симптомами дезадаптивної поведінки дітей таких дітей $є$ надмірна агресивність, упертість, емоційна неврівноваженість, конфліктність. Отже, дизонтогенез комунікативно-мовленнєвого розвитку дітей молодшого шкільного віку із мовленнєвими порушеннями провокує значні поведінковому зміни.

Перспективами подальших наукових розвідок вбачаємо проведення емпіричного дослідження взаємозв'язку самооцінки, саморегуляції, тривожності й стилю поведінки дітей молодшого шкільного віку, які мають мовленнєві порушення.

\section{Лimepamypa:}

1. Барабаш, O.O. (2016). Поведінка людини: підходи до розуміння. URL: http://ena.lp.edu.ua/bitstream/ntb/37229/1/2_4-8.pdf

2. Бочелюк, В.Й. (2017). Соціально-психологічні мотиви і механізми поведінки людини в суспільстві Психологічні перспективи. Випуск 30, 2017 C.18-28. URL: http://psychoprospects.vnu.edu.ua/index.php/psychoprospects/article/view/207/18

3. Гарасимів, Т. (2016). Поведінка людини: філософсько-правова рефлексія «діяльність» та «активність». Вісник Національного університету «Львівська політехніка». Серія: Юридичні науки: збірник наукових праць. 2016. № 855. С. 147-151.

4. Максименко, С. (2019). Теорія розвитку поведінки людини П.П. Блонського. Збірник наукових праць «Проблеми сучасної психології», (29). 2015. С. 7-18.

5. Матющенко, I.M (2012). До проблеми соціалізації дітей з тяжкими порушеннями мовлення. Логопедія. 2012. №2. С. 53-56.

6. Лист МОН (30.08.2021). Методичні рекомендації щодо організації навчання осіб з особливими освітніми потребами. Лист $\mathrm{MOH}$ №1/9-436 від 30.08.2021. URL: https://mon.gov.ua/ua/news/metodichni-rekomendaciyi-shodo-organizaciyi-navchannyaosib-z-osoblivimi-osvitnimi-potrebami-list-mon 
7. Осауленко, Л.А. (2014). Формування моральної поведінки учнів 3 вадами розвитку: методичний посібник. Золотоноша, 2014. $100 \mathrm{c.}$

8. Панчишин, P.І. (2016). Детермінанти поведінки людини: філософсько-правовий вимір: дисертація на здобуття наукового ступеня кандидата юридичних наук: 12.00 .12 філософія права. Львів, 2016. 205 с.

9. Психологічнгий словник (2015). Психологічний словник. Сергєєнкова, О.П. Видавництво Науковий світ. 2015. URL: https:/elibrary.kubg.edu.ua/id/eprint/5980/3/ O_Serhieienkova_IL.pdf

10. Рібцун, Ю.В. (2020). Учні початкових класів із тяжкими порушеннями мовлення: навчання та розвиток: навч.-метод.посіб. Львів: Світ, 2020. 246 с.

11. Національна Асамблея людей 3 інвалідністю України (5 липня 2021). Урядом прийнято зміни до Національної стратегії реформування системи інституційного догляду та виховання дітей на 2017-2026 роки. Національна Асамблея людей з інвалідністю України. 5 липня 2021. URL: https://naiu.org.ua/uryadom-pryjnyato-zminy-do-natsionalnoyi-strategiyireformuvannya-systemy-instytutsijnogo-doglyadu-ta-vyhovannya-ditej-na-2017-2026-roky/

12. Філософський енциклопедичний словник (2002). Наук. ред.: Л. В. Озадовська, Н. П. Поліщук. Київ: Абрис, 2002. 751 с.

13. Щербакова I, Харченко Т. (2021). Особливості самооцінки та саморегуляції поведінки дітей молодшого шкільного віку із мовленнєвими порушеннями. Педагогічні науки: теорія, історія, інноваційні технології: наук. журнал / голов. ред. А. А. Сбруєва. Суми: Вид-во СумДПУ імені А. С. Макаренка, 2021. № 5 (109).

14. Dixie, Jordan (2005). Functional Behavioral Assessment and Positive Interventions: What Parents Need to Know URL: https://www.wrightslaw.com/info/discipl.fba.jordan.pdf

15. Shcherbakova Iryna, Kharchenko Tamara, Yarkova Adelina. Education for children with special educational needs amid the pandemic. Actual trends of modern scientific research. Proceedings of the 11th International scientific and practical conference. MDPC Publishing. Munich, Germany. 2021. Pp. 362-365. URL: https://sci-conf.com.ua/wpcontent/uploads/ 2021/06/ACTUAL-TRENDS-OF-MODERN-SCIENTIFIC-

RESEARCH-6-8.06.2021.pdf\#page=362

16. Waller, M., Sollod, R., Sander, E., Kunicki, E. (1983). Psychological Assessment of Speech- and Language-Disordered Children. URL:https://pubs.asha.org/doi/ pdf/10.1044/0161-1461.1402.92

\section{References:}

1. Barabash, O.O. (2016). Povedinka liudyny: pidkhody do rozuminnia [Human behavior: approaches to understanding]. [in Ukrainian].

URL: http://ena.lp.edu.ua/bitstream/ntb/37229/1/2_4-8.pdf

2. Bocheliuk, V.I. (2017). Sotsialno-psykholohichni motyvy i mekhanizmy povedinky liudyny v suspilstvi [Socio-psychological motives and mechanisms of human behavior in society]. Psykholohichni perspektyvy - Psychological perspectives. Vypusk 30, 2017. S. 18. [in Ukrainian].

URL: http://psychoprospects.vnu.edu.ua/index.php/psychoprospects/article/view/207/18

3. Harasymiv, T. (2016). Povedinka liudyny: filosofsko-pravova refleksiia «diialnist» ta «aktyvnist» [Human behavior: philosophical and legal reflection «activity» and «activity»]. Visnyk Natsionalnoho universytetu «Lvivska politekhnika». Seriia: Yurydychni nauky: zbirnyk naukovykh prats. 2016. № 855. S. 147-151. [in Ukrainian].

4. Maksymenko, S. (2019). Teoriia rozvytku povedinky liudyny P.P. Blonskoho [The theory of human behavior development PP Blonsky]. Zbirnyk naukovykh prats «Problemy suchasnoi psykholohii» (29). 2015. S. 7-18. [in Ukrainian]. 
5. Matiushchenko, I.M (2012). Do problemy sotsializatsii ditei z tiazhkymy porushenniamy movlennia [To the problem of socialization of children with severe speech disorders]. Lohopediia. 2012. №2. S. 53-56. [in Ukrainian].

6. Lyst MON (30.08.2021). Metodychni rekomendatsii shchodo orhanizatsii navchannia osib z osoblyvymy osvitnimy potrebamy. Lyst MON №1/9-436 30.08.2021 [Methodical recommendations on the organization of training of persons with special educational needs - Letter of the Ministry of Education and Science] [in Ukrainian].

URL: https://mon.gov.ua/ua/news/metodichni-rekomendaciyi-shodo-organizaciyi-navchannyaosib-z-osoblivimi-osvitnimi-potrebami-list-mon

7. Osaulenko, L.A.(2014). Formuvannia moralnoi povedinky uchniv z vadamy rozvytku: metodychnyi posibnyk [Formation of moral behavior of students with developmental disabilities: a manual]. Zolotonosha. 2014. 100 s. [in Ukrainian].

8. Panchyshyn, R.I. (2016). Determinanty povedinky liudyny: filosofsko-pravovyi vymir [Determinants of human behavior: the philosophical and legal dimension]. dysertatsiia na zdobuttia naukovoho stupenia kandydata yurydychnykh nauk: 12.00.12 - filosofiia prava Lviv. 2016. - 205 s. [in Ukrainian].

9. Psykholohichnhyi slovnyk (2015). Psykholohichnyi slovnyk Serhieienkova, O.P. [Psychological dictionary Sergeenkova, OP]. Vydavnytstvo Naukovyi svit. [in Ukrainian].

URL: https://elibrary.kubg.edu.ua/id/eprint/5980/3/O_Serhieienkova_IL.pdf

10. Ribtsun, Yu.V. (2020). Uchni pochatkovykh klasiv iz tiazhkymy porushenniamy movlennia: navchannia ta rozvytok [Elementary school students with severe speech disorders: learning and development]: navch.-metod.posib. Lviv: Svit, 2020. 246 s. [in Ukrainian].

11. Natsionalna Asambleia liudei z invalidnistiu Ukrainy (5 lypnia 2021). Uriadom pryiniato zminy do Natsionalnoi stratehii reformuvannia systemy instytutsiinoho dohliadu ta vykhovannia ditei na 2017-2026 roky [National Assembly of People with Disabilities of Ukraine (July 5, 2021). The Government has adopted amendments to the National Strategy for Reforming the System of Institutional Care and Upbringing of Children for 2017-2026]. Natsionalna Asambleia liudei z invalidnistiu Ukrainy. 5 lypnia 2021. [in Ukrainian].

URL: https://naiu.org.ua/uryadom-pryjnyato-zminy-do-natsionalnoyi-strategiyireformuvannya-systemy-instytutsijnogo-doglyadu-ta-vyhovannya-ditej-na-2017-2026-roky/

12. Filosofskyi entsyklopedychnyi slovnyk, (2002). Filosofskyi entsyklopedychnyi slovnyk / nauk. red.: L. V. Ozadovska, N. P. Polishchuk [Philosophical encyclopedic dictionary]. Kyiv: Abrys, 2002. 751 s. [in Ukrainian].

13. Shcherbakova I, Kharchenko T. (2021). Osoblyvosti samootsinky ta samorehuliatsii povedinky ditei molodshoho shkilnoho viku iz movlennievymy porushenniamy [Features of selfassessment and self-regulation of behavior of children of primary school age with speech disorders]. Pedahohichni nauky: teoriia, istoriia, innovatsiini tekhnolohii. Sumy: Vyd-vo SumDPU imeni A. S. Makarenka, 2021. № 5 (109). [in Ukrainian].

14. Dixie, Jordan (2005). Functional Behavioral Assessment and Positive Interventions: What Parents Need to Know. URL: https://www.wrightslaw.com/info/discipl.fba.jordan.pdf

15. Shcherbakova Iryna, Kharchenko Tamara, Yarkova Adelina. Education for children with special educational needs amid the pandemic. Actual trends of modern scientific research. Proceedings of the 11th International scientific and practical conference. MDPC Publishing. Munich, Germany. 2021. Pp. 362-365. URL: https://sci-conf.com.ua/wp-content/uploads/2021/06/ ACTUAL-TRENDS-OF-MODERN-SCIENTIFIC-RESEARCH-6-8.06.2021.pdf\#page=362

16. Waller, M., Sollod, R., Sander, E., Kunicki, E. (1983). Psychological Assessment of Speech- and Language-Disordered Children. URL: https://pubs.asha.org/doi/pdf/10.1044/01611461.1402 .92

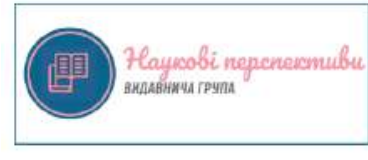

